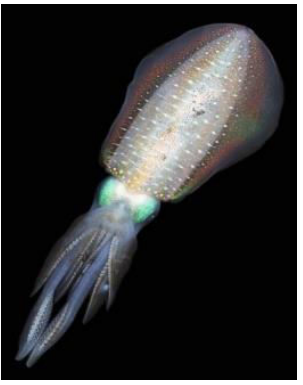

International Journal of Zoological Investigations

Contents available at Journals Home Page: www.ijzi.net

\title{
Fish Assemblage of the Una Biological Reserve, Bahia, Brazil
}

\author{
Flores-Lopes Fábio ${ }^{{ }^{*}}$ and Silva Augusta M. ${ }^{2}$ \\ ${ }^{1}$ Department of Biological Sciences, State University of Santa Cruz, Jorge Amado Highway, km 16, 45662 -000, Ilhéus, BA, Brazil \\ 2Biologist, Master in Tropical Aquatic Systems; State University of Santa Cruz - UESC, Jorge Amado Highway, km 16, 45662-000, \\ Ilhéus, BA, Brazil
}

*Corresponding Author

Received: $11^{\text {th }}$ December, 2020

Accepted: $18^{\text {th }}$ February, 2021

Published online: $1^{\text {st }}$ March, 2021

https://doi.org/10.33745/ijzi.2021.v07i01.007

\begin{abstract}
The Biological Reserve of Una, located in the south of Bahia, is a region with very little information about the composition, diversity and spatial distribution of the species. The objective of the present study was to know the composition and structure of the fish assembly of the streams of Biological Reserve of Una - REBIO. Four sampl es were taken at seven points distributed in six streams, one being outside the reserve limits, between February 2011 and March 2012. The specimens were captured with trawls of the picaré and puçá type. In the field, the specimens were anesthetized, fixed in $10 \%$ formaldehyde and placed in $70 \%$ alcohol. The species were identified with specialized bibliography. The specimens that remained in doubt were sent to specialists from the Federal University of Rio Grande do Sul (UFRGS) and Pontifical Catholic University of Rio Grande do Sul (PUCRS) for identification. Then the material was deposited in the scientific collection of the State University of Santa Cruz (UESC). The occurrence constancy index, Shannon Diversity Index, Margalef Wealth and the Pielou Equity index were applied. In the ecological indexes, the ABC curves and the MDS ordering method were calculated. A similarity matrix was calculated from the Bray Curtis index. W statistic consisting of a numerical summary of the ABC curve was applied. The $t$ - test was used to verify the level of significance at $95 \%$. A total of 5549 individuals belonging to 4 orders, 9 families and 22 species were collected, of which 8 had ind efinite taxonomic status, which confirms that the region is little explored from the point of view of the ichthyofauna. The results indicate the dominance of opportunistic species and demonstrate the influence of environmental conservation on the composition of the fish congregation. The lack of studies in the region and hum an occupation reflect the presence of undescribed species and the risk of extinction and the creation of a conservation strategy.
\end{abstract}

Keywords: Ecology, Ichthyofauna, Ecological indexes

Citation: Flores-Lopes Fábio and Silva Augusta M.: Fish assemblage of the Una Biological Reserve, Bahia, Brazil. Intern. J. Zool. Invest. 7 (1): 67-81, 2021.

https://doi.org/10.33745/ijzi.2021.v07i01.007 


\section{]Introduction}

The conservation of terrestrial fauna and flora has been the main justification for the establishment of environmental protection areas in the last three decades in Brazil, and the extreme south of Bahia corresponds to a region of great importance for the conservation of biodiversity and where they are concentrated as the largest Atlantic Forest reserves in the Brazilian Northeast (Sarmento-Soares et al., 2007).

According to Cetra et al. (2010), defining the smallest area that can protect the greatest diversity is a complex challenge that has as a first step to know what species occur in a given region. In Southern Bahia, these authors point out that the information about natural fish populations is incomplete, lacking detailed knowledge about species richness, distribution patterns and population biology.

Recent surveys of freshwater fish in the region resulted in the description of new species, in the identification of endangered species, and the data revealed the presence of endemic species while others had their geographical distribution extended (Cetra and Petrere Jr., 2006; Cetra et al., 2009; MartinesPinheiro, 2006 a, b). Despite the growing knowledge of the region's richness, it contrasts with information on natural fish populations, such as species, their distribution patterns and their population biology (Cetra et al., 2010). The results also demonstrate the presence of several species to be described (Sarmento-Soares, 2007).

The region of southern Bahia is known as one that has very little information about the diversity of individuals, organization, composition and spatial distribution of species (Cetra et al., 2009). The small anthropic alteration on these areas still forested, according to these authors, suggests that their ichthyofaunistic composition is close to the original. According to Rosa and Menezes (1996), fish correspond to more than half of recent vertebrates, which are little considered in regional estimates of biodiversity and conservation.

Fish assemblages in most reservois incluse both native and introduced species in a nonnaturally occoring habitat that is subject of fluctuation in deph or other human regulation (Araújo and Santos, 2001). The hydrological wealth in the extreme south of Bahia is contrasting in relation to the little-known fish fauna (Sarmento-Soares et al., 2007).

In a study carried out for the Una Biological Reserve management plan (MMA, 1997), several specimens of the fauna and flora were verified. No survey of the ichthyofauna of the region was carried out, probably because the species were rare or endemic, being constituted in exemplars of great importance in the elaboration of management plans. According to Thomas et al. (1998), the environments that demonstrated a biological richness, related to the significant levels of endemism of fauna and flora and to the high degree of fragmentation of the remaining forest ecosystems, were considered important.

However, it is important to note that in order to reduce the risk of extinction and to note that there is a high risk of extinction (Sarmento-Soares et al., 2007). Studies in regions that preserve natural features and which have suffered little human interference are important references for public conservation policies and understanding of 
the composition and distribution of aquatic communities in intact environments is pressing given the accelerated environmental degradation observed in a number of limnic ecosystems (Duncan and Lockwood, 2001).

The objective of the present study was to characterize the fish assemblage in order to allow the knowledge, composition and structure of the ichthyofauna of REBIO - Una, Brazil.

\section{Materials and Methods}

\section{Study area}

The Una Biological Reserve (REBIO Una) is an integral protection unit of the World Heritage Site, Atlantic Forest Reserve of the Discovery Coast, and is part of the Mata Atlântica Biosphere Reserve (Fig. 1). It is located to the south of the state of Bahia, distant about 13 $\mathrm{km}$ from the seat of the municipality of Una $\left(15^{\circ} 00^{\prime}-15^{\circ} 15^{\prime} \mathrm{S}\right.$ and $30^{\circ} 00^{\prime}-30^{\circ} 15^{\prime} \mathrm{W}$ ) (MMA, 1997). The region presents a warm and humid climate, without a well defined dry season and has typical ecosystems of the Atlantic Forest biome of this stretch of the coast (MMA, 1998).

The hydrography of Rebio-Una is formed by several rivers and streams, the main one being the Serra river, whose headwaters are contained in the reserve, and can be cited as its main tributaries -- the São Caetano stream and the Rosario river. The Serra river is born in the western portion of Rebio-Una and flows into the Maruim river, the region's main watercourse and natural border northwest of the reserve (MMA, 1997).

In these watercourses the sampling points are located: Point 1 - São Caetano stream $\left(39^{\circ}\right.$ 03' 36" W - 15 12' 34" S); Point 2 - Rosário

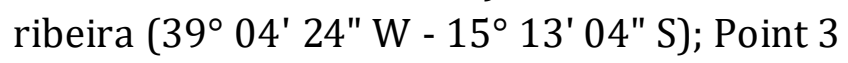

- Serra river $\left(39^{\circ} 04^{\prime} 32^{\prime \prime} \mathrm{W}-15^{\circ} 13^{\prime} 52^{\prime \prime} \mathrm{S}\right)$; Point 4 - Maruim river $\left(39^{\circ} 05^{\prime} 13^{\prime \prime} \mathrm{W}-15^{\circ}\right.$ 08' 22" S); Point 5 - Miriguim river $\left(39^{\circ} 08^{\prime}\right.$

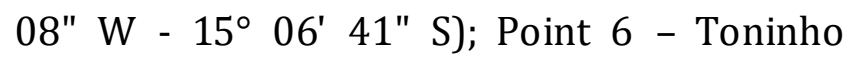
stream $\left(39^{\circ} 10^{\prime} 42^{\prime \prime} \mathrm{W}-15^{\circ} 07^{\prime} 17^{\prime \prime} \mathrm{S}\right)$ and Point 7 - Maruim river $\left(39^{\circ} 09^{\prime} 31^{\prime \prime} \mathrm{W}-15^{\circ}\right.$ $05^{\prime} 38^{\prime \prime}$ S). Unlike the others, section 7 is located outside the reserve limits in a village called Vila Brasil (Fig. 2).

In spite of being considered "restricted", by the categorization of the Conservation Unit, despite the modification of the state of the landscape, which suggests the maintenance of an excellent state of conservation (Souza, 2009). A REBIO - Una suffers the acquisition of land (1976) and as a result the reflection of the invasion of farmers between the period of acquisition and that of the official decree. In this way, the sampling sections are marked by the presence of isolated dwellings, removal of the original vegetation converted to pasture and agricultural activities, and also by the construction of bridges at points 1, 3, 6 and 7 . The point 6 has the narrowest channel as a function of the construction of a bridge and point 7 has the widest section.

\section{Data Collect}

Our samplings were carried out between February 2011 and March 2012, in each of the seven points of six streams of the Una biological reserve, with trawls of the picaré type (5.5 m long, $1.5 \mathrm{~m}$ tall and mesh of 0.5 cm) (Malabarba and Reis, 1987). The specimens were anesthetized, still in the field, by substance MS222 (Ethyl 3-aminobenzoate methanesulfonate salt) at a concentration of $200 \mathrm{mg} / \mathrm{L}$, fixed in $10 \%$ formaldehyde and then transferred to $70 \%$ alcohol. The species identification was performed with the aid of specialized bibliographical material (Melo et 


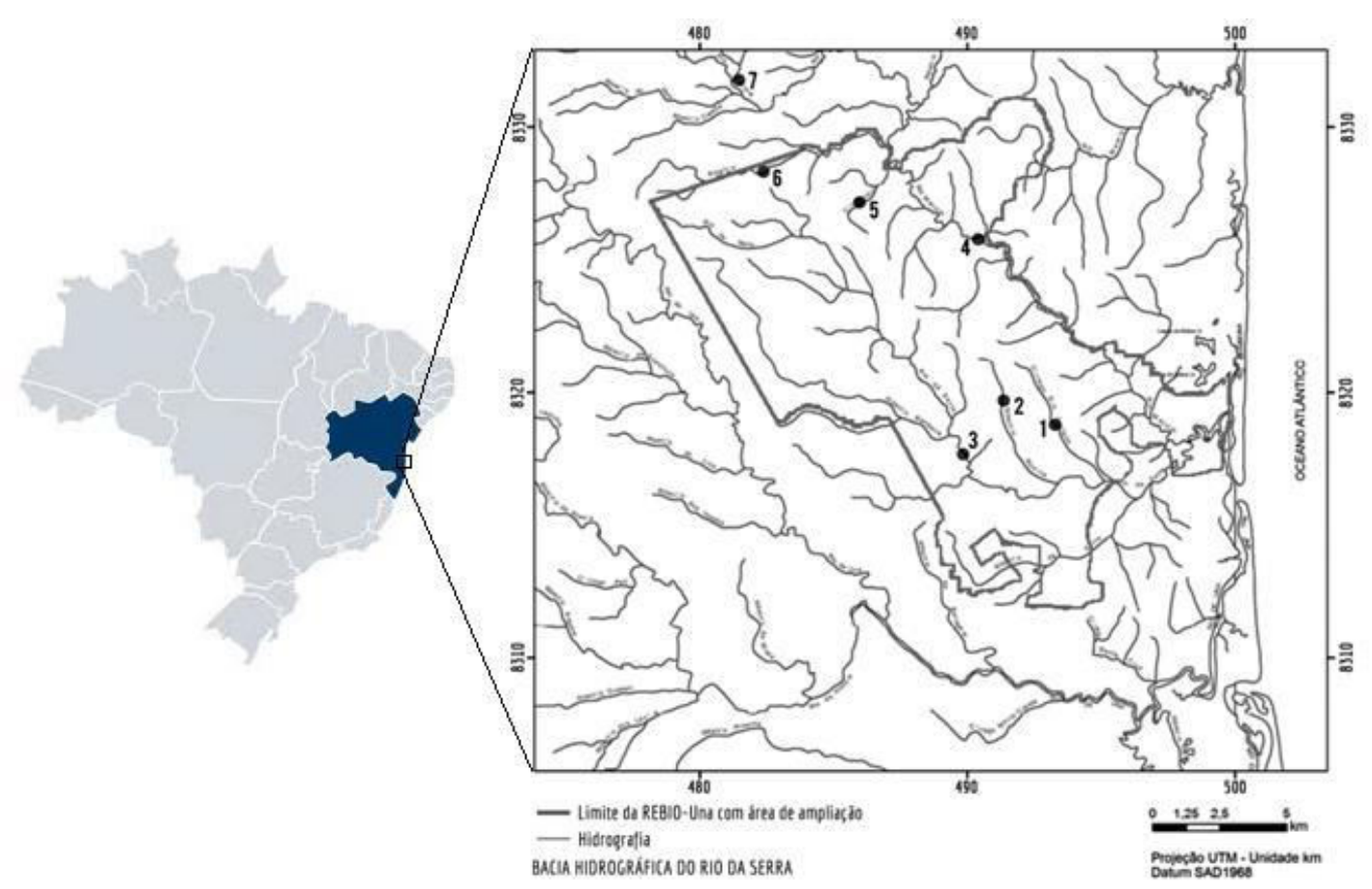

Fig. 1: Map of Brazil, Bahia and UNA Biological Reserve with the location of sampling points. 1 - São Caetano Stream, 2 - Rosario Stream, 3 - Serra river, 4 Maruim river, 5 - Miriguim river, 6 - To ninho Stream and 7 Maruim river.

al., 2005; Oyakawa et al., 2006; Menezes et al., 2007). The specimens that remained in doubt were sent to specialists from the Federal University of Rio Grande do Sul (UFRGS) and Pontifical Catholic University of Rio Grande do Sul (PUCRS) for identification. Subsequently the specimens were deposited in the scientific collection of the State University of Santa Cruz (UESC).

\section{Data analysis}

In order to characterize the ichthyofauna, the Constancy index of occurrence was calculated where a species is considered constant when present in more than $50 \%$ of the samples, ancillary when present in 25 to $50 \%$ of samples and accidental species when present in less than 25\% of samples (Dajoz, 1983). Measurements of weight (g) and standard length $(\mathrm{cm})$ were taken individually, by means of analytical balance and digital caliper respectively.
The Shannon Diversity Indexes $\left(\mathrm{H}^{\prime}=-\Sigma \mathrm{pi}\right.$ lnpi, where: $p i=$ proportion of species to the captured total and $\mathrm{ln}=$ neperian logarithm), the Margalef Wealth $(D=(S-1) / \mathrm{ln}$. S= number of species, $1=$ number of individuals and $\mathrm{ln}=$ neperian logarithm) and the index of Pielou Equability ( $E^{\prime}=\mathrm{H}^{\prime} / \mathrm{Hmax}$, where: $\mathrm{Hmax}=\log \mathrm{S}$ and $S=$ number of species). The t-test was used to verify the level of significance at $95 \%$. These analyses were calculated using the Past 1.11 program.

The ABC (Abundance-Biomass-Curve) curves were calculated in order to verify the relationship between relative abundance in body mass and number of individuals in the different points sampled, along with the $\mathrm{W}$ statistic consisting of a numerical summary of the ABC curve. The Multi-Dimensional Scaling (MDS) was applied to identify the groupings between the points. The similarity matrix was calculated from the Bray Curtis index 

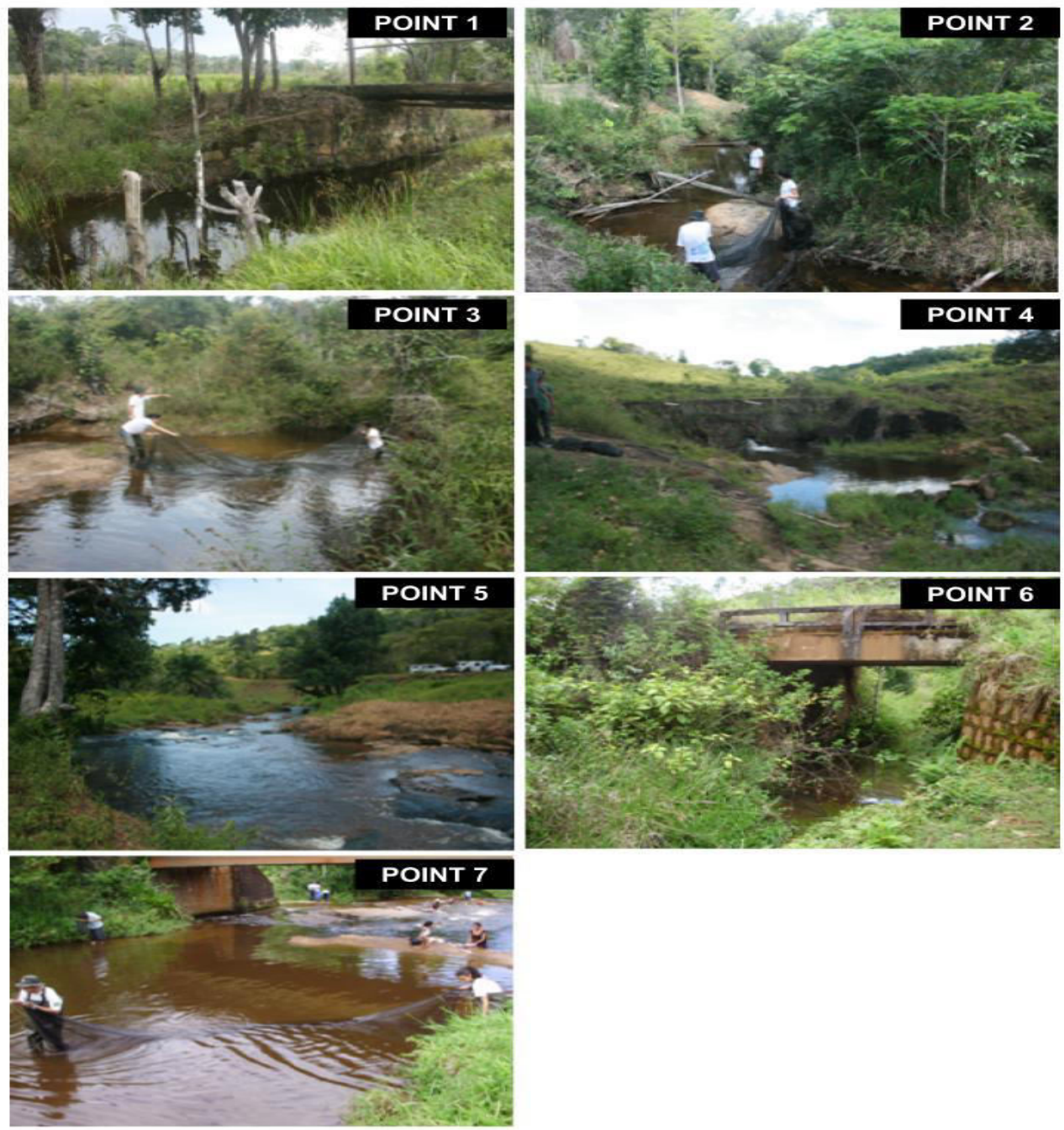

Fig. 2: Photos of the sampling points in the REBIO - UNA. Point 1 - São Caetano, Point 2 - Rosário ribeira, Point 3 - Serra river, Point 4 - Maruim river, Point 5 - Miriguim river; Point 6 - Toninho stream and Point 7 - Maruim river.

considering the transformation by square root. These tests were performed using Primer 6.0 software.

\section{Results}

\section{Composition of the Ichthyofauna}

5549 individuals were captured, distributed in 4 orders, 9 families and 22 species, 8 of them with indefinite taxonomic status (Table 1). The most representative order was Characiformes (83\%), followed by Cyprinodontiformes (9\%), Perciformes (6\%) and Siluriformes (2\%). The families that presented the highest percentage were Characidae (82\%), Poeciliidae (9\%) and Cichlidae (6\%), with 6 remaining families totaling $3 \%$.

The order Characiformes occurs in almost all samples, with 6 genera and 11 species distributed in at least two sampling points, except for Hoplerythrinus unitaeniatus (Agassiz, 1829) and Astyanax sp., which occurred only at points 4 and 7 , respectively.

The specimens of the order Cyprinodontiformes were verified in the 4 
Table 1: List of species and numbers of individuals sampled at REBIO - UNA, Bahia, Brazil

\begin{tabular}{llc}
\hline ORDER / FAMILY SPECIES & No. IND. \\
\hline
\end{tabular}

Characiformes

Characidae

Astyanax bimaculatus (Linnaeus, 1758)

82

Astyanax burgerai Zanata \& Camelier, $2009 \quad 3896$

Astyanax aff fasciatus (Curvier, 1819) 481

Astyanax sp (Bird e Girard, 1854) 4

Hyphessobrycon luetkenii (Boulenger, 1887) 84

Oligossarcus macrocepis (Steindachner, 1877) 16

Oligosarcus sp (Cuvier, 1829) 9

Crenuchidae $\quad$ Characidium sp (Reinhardt, 1867) 35

$\begin{array}{lll}\text { Erythrinidae } & \text { Hoplerythrinus unitaeniatus (Agassiz, 1829) } & 1\end{array}$

Hoplias malabaricus (Bloch, 1794) 9

Hoplias sp (Bloch, 1794) 3

\section{Cyprinodontiformes}

Poecillidae

Poecilia reticulata Peters, 1859

Poecilia vivipara Block \& Schneider, 1801

\section{Perciformes}

Cichilidae

Geophagus brasiliensis ( Quoy \& Gaimard, 1824)

Geophagus sp (Heckel, 1840)

Gobiidae

Awaous tayasica Lichtenstein, 1822

\section{Siluriformes}

Callichthidae

Scleromystax lacerdai (Hieronimus, 1995 )

Callichthys callichthys (Linnaeus, 1758)

Loricaridae

Aspidoras sp ( Nijssen \& Isbrücker, 1976)

Pareiorhaphis bahianus (Gosline, 1947)

Rineloricaria sp (Kner, 1853) 
samplings, represented by only one genus and two species, Poecilia vivipara (Block and Schneider, 1801) and Poecilia reticulata (Peters, 1859), both exotic. No records of individuals of these species were found for points 1,2 and 3.

The order Perciformes was represented by only 2 genera and 3 species: Awaous tajasica (Lichtenstein, 1822), Geophagus sp (Heckel, 1840) and Geophagus brasiliensis (Quoy and Gaimard, 1824), the latter being recorded at all sampling points.

The order Siluriformes represented 6 genera and 6 species, generally found in environments with rocky bottom and little current. Most of the individuals were verified at point 7, where the Pareiorhaphis bahianus (Gosline, 1947) species presented 95\% of the records at this place, with no records of individuals of this order at points 3 and 4 .

Astyanax burgerai (Zanata and Camelier, 2009) was the most abundant, accounting for $70 \%$ of the total number of individuals followed by the Astyanax aff. fasciatus (Curvier, 1819), with 9\%, Geophagus brasiliensis (Quoy and Gaimard, 1824) (6\%), Poecilia vivipara (Bloch and Schneider, 1801) (6\%) and Poecilia reticulata (Peters, 1859) $(3 \%)$, while the other species had values lower than 3\% each. The species Poecillia vivipara and Poecillia reticulata, considered exotic, represented $8.6 \%$ of the individuals collected.

Only species G. brasiliensis and A. burgerai were considered constant, both dominant at most points, while 6 species were considered as accessory: A. bimaculatus, A. aff fasciatus, Oligossarcus macrocepis (Steindachner, 1877), P. reticulata, $P$. vivipara and Characidium sp. The remaining 13 species were considered to be accidental, such as Astyanax sp., $H$. unitaeniatus, Scleromystax lacerdai (Hieronimus, 1995), Callichthys callichthys (Linnaeus, 1758) and Rineloricaria sp., each occurring in only one stream.

The total biomass collected was $6.3 \mathrm{~kg}$, with $A$. burgerai accounting for $52.7 \%$ of this value. The highest weights were of the species Rham dia sp. (82.8 g), Hoplias sp. (53.4 g) and H. malabaricus (46.49 g) and the lowest weights were Aspidoras sp. (0.13 g) and Characidium sp. (0.15 g). The species with the highest standard length Rhamdia sp $(18 \mathrm{~cm})$ and the lowest in the species Poecillia reticulata, $(1 \mathrm{~cm})$.

\section{Ecological indices}

The diversity ranged from 0.05 at point 2 in the second collection to 1.58 at point 7 of the third collection. Point 7 was the one that maintained the highest values of diversity throughout the sampling period, and only at this point were the species Astyanax sp and Rineloricaria sp. Of the total sampled species, $43 \%$ of the individuals observed were collected at point 2 during the second sampling, and $99.2 \%$ of them were represented by a single species (A. burgerai).

The highest value of richness index was verified at point $7(1,84)$ in the third sample, where 97 individuals were observed from 7 species. The lowest value was verified at point 6 (0.36) in the first collection, where 276 individuals were distributed in 3 species: $G$. brasiliensis, A. burguerai and P. reticulata.

The equability was lower at point $2(0.07)$ during the third collection, where A. burgerai represented $98 \%$ of individuals and higher at point 3 (0.95) during the first collection, where Characidium sp. (n=1), Geophagus sp. 
$(\mathrm{n}=2)$ and 0 . macrocepis $(\mathrm{n}=1)$ were recorded. There was no statistically significant difference between the points sampled $(\mathrm{P}<0.05)$ for any of the indices during the study period.

The $\mathrm{W}$ statistic for the relation between biomass and abundance indicated that species dominance is higher in number of individuals than in body mass. The curves showed two configurations, one for points $1,2,3,4,5$ and 7 , where the abundance was above the biomass $(\mathrm{w}<0)$ and another for the point 6 ( $w>0$ ) where the biomass curve above the abundance curve. At this point the biomass is dominated by a small number of individuals that present greater body weight as is the case of H. malabaricus and Hoplias sp. (Fig. 3).

It was verified through the MDS analysis a greater abundance at points 1,2 and 3 and at point 6 a greater biomass check. At points 4, 6 and 7 there was a certain equivalence between the two items. It was possible to verify that at point 7 this equivalence was more intense. MDS analysis also showed a greater proximity between points 5 and 7 and greater spatial distance between points 2 and 7 , but the formation of clusters was not evidenced. The circles projected in the graph demonstrate that the species $A$. burgerai presented the lowest occurrence at points 5 and 7 and higher occurrence at point 2 (Fig. 4).

\section{Discussion}

The neotropical region contains the largest diversity of freshwater fish in the world (Malabarba, 1998). In this area, the most representative orders and most of the specimens of this group can be observed. In southern Bahia, according to Menezes (1997), there is a marked endemism in the coastal drainage region from Rio de Janeiro to southern Bahia, which can be exemplified by the species with exclusive distribution and the possibility of affirming that the area has a distinct faunal composition. Sarmento-Soares et al. (2006) pointed out that the species Trichomycterus pradensis and Microglanis patoxo presented endemism in the basins of the extreme south of Bahia.

Despite the increase in the number of works carried out in the region, it is evident that species description studies are needed, since many have not yet been cataloged. Most of the species initially recorded are classified as indefinite taxonomic status. When collecting different species, Cetra et al. (2009, 2010) observed a large number of species with indefinite taxonomic status, due to the fact that they are insufficiently known in the studied areas, but are of probable biological importance and that they may represent new species, which reveals the need for new surveys. in the region. According to Menezes et al. (2007), the small size of specimens of the species refer to the occupation of microenvironments by these small organisms and the possibility of them completing the life cycle in restricted geographical areas, suggesting endemism.

Situations such as this demonstrate the necessity of carrying out more detailed taxonomic studies on these specimens, so that they are precisely identified or described as new species. The results agree with the proposition that there is a lack of information about the region's ichthyofauna (SarmentoSoares et al., 2007; Cetra et al., 2010) and indicates the importance of conservation of this environment due to the risk of some species being extinct before being described. 

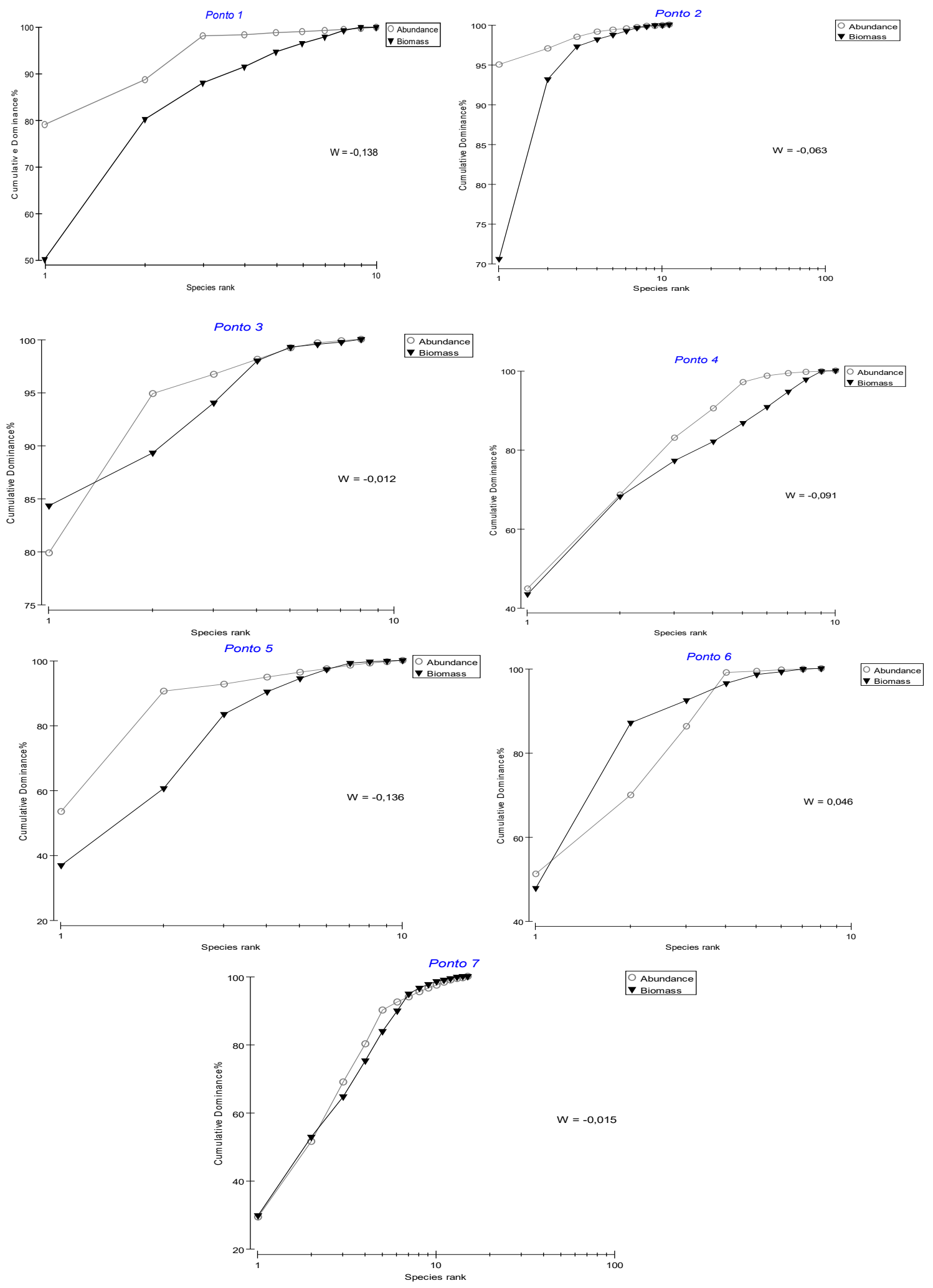

Fig. 3: ABC curves for each of the sample points. Abundance and Biomass. Point 1 - São Caetano, Point 2 Rosário rib eira, Point 3 - Serra river, Point 4 - Maruim river, Point 5 - Miriguim river; Point 6 - Toninho stream and Point 7 - Maruim river. 


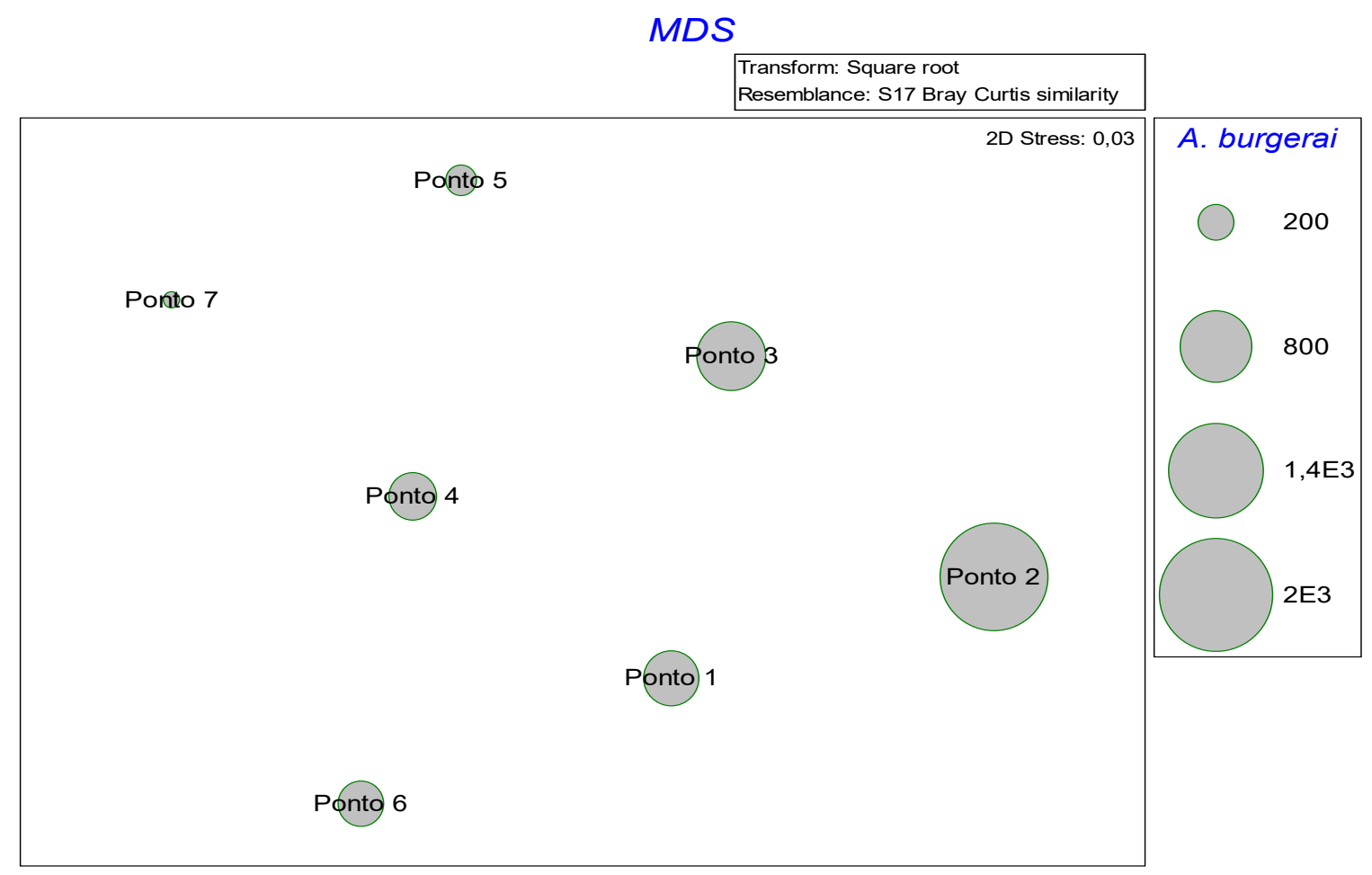

Fig. 4: MDS cluster analysis, gray the projection of the numerically dominant taxon. Point 1 - São Caetano, Point 2 - Rosário ribeira, Point 3 - Serra river, Point 4 - Maruim river, Point 5 - Miriguim river; Point 6 - Toninho stream and Point 7 - Maruim river.

Still few works were done in the region, and the articles by Cotes et al. (2007), Amorim et al. (2009), Cotes and Morel (2011), Aguiar et al. (2012) and Sollberg et al. (2014) have not used Ichthyofauna as an object of study in order to evaluate its composition and structure. In this context, few studies exis in which aquatic environments and organisms have been taken into account in the delimitation of these protected areas (Cetra et al., 2010). No ichthyological study was carried out for Biological Reserve of Una, even though it has been more than thirty years since its creation (Teodosio, 2012).

In the Una Ecological Reserve, REBIO Una, 4 of the 18 orders of freshwater fish occurring in Brazil were registered, with the highest percentage of individuals represented by Characiformes, which corroborates the pattern described by Lowe- McConnell (1999), for non-estuarine rivers and streams of the neotropical region. In this work, the largest number of species of the Characidae family was observed, and the species that presented the most frequent sampling was Astyanax burgerai (Zanata and Camelier, 2009). The result observed in this study is in agreement with Reis et al. (2003), who analyzed similar samples from the South and Central America.

The species $A$. burgerai with $G$. brasiliensis stands out for its consistency in the samplings. The Astyanax genus, with about 100 species described, is one of the most common in the Neotropical basins and its high occurrence of individuals for the region has been portrayed in several studies (Sarmento-Soares et al., 2007; Cetra et al., 2009). Garutti and Britski (2000) reported that the distribution of 
Astyanax in the most diverse habitats in the Brazilian watersheds may be related to its trophic plasticity. Specimens of this genus can also perform larger displacements, overcoming obstacles and may occupy several stretches of the basin (Aquino, 2009).

This set of information can also apply to the occurrence of $G$. brasilensis in all the stretches, since it is an opportunistic species that has its diet influenced by the availability of resources in the environment (Teixeira et al., 2005). According to Aquino (2009), the small size of the streams and the irregularity of the stretches are factors that favor the occurrence of species characterized by plasticity and resistance to abiotic variations.

The substrate influences diversity by limiting the presence of species in a given habitat (Araújo, 2001). Thus, the absence of siluriformes at points 3 and 4 may be associated with the presence of the sandy substrate. Guimarães et al. (2010) observed an association between the decrease in the number of individuals of this order and the gradual reduction of the granulometry of the substrate. It was verified at point 7 having a greater abundance of the loricarídeos, rocky place and of strong current. The results were corroborated by the studies of Melo et al. (2005). The occurrence of similar data can be explained by the food strategy of these species, since they are based on rocks and feed on microorganisms adhered to the substrate (Casatti, 2002).

This point, being located outside the reserve area, is the most anthropized place, thus being subject to the presence of several environmental stressors. These types of factors compromise the survival of various organisms. Deforestation intensifies the loading of light particles, making it difficult to establish structurally more complex substratum-dependent photosynthetic organisms and, consequently, affects allochthonous and autochthonous production (Ferreira and Cassati, 2006). The presence of these characteristics alters the diversity of both fish and food resources, directly or indirectly compromising the food chain (Gomiero and Braga, 2005). Harding et al. (1998) argue that the maintenance of aquatic diversity may require the conservation of most or all of the river basin. Thus, the preservation of its natural characteristics and the promotion of restoration of degraded riparian areas adjacent to the reserve is essential for the maintenance of the high diversity of species in its rivers.

On the other hand, some species favored the situation observed at the points. The fact that the species $H$. unitaeniatus is recorded only at point 4 , a section of retention and with pasture, can be explained by its capacity of resistance to the abiotic variations, since, in this section, changes such as water level or temperature in a short period cause drastic changes, providing a new environment. This result may indicate that, in this environment, H. unitaeniatus finds favorable conditions for its survival. Similar results were reported by Polez et al. (2003) and Leal et al. (2010), who verified the establishment of the species in places with high temperatures and that this species presents morphological adaptations that guarantee the capacity to survive long periods of hypoxia. Teodosio (2012) observed that this is the most visibly modified point and that it presented the highest percentage of exotic species.

The transformation of riparian forests into pastures influences the increase of the light 
incidence, decreasing the oxygen of the water and may lead to the death of certain individuals and to benefit others such as the Poecilia genus (Vieira and Shibatta, 2007). The highest occurrence of these species in pasture stretches resembles the results found by Sarmento-Soares (2007) who found dominance of these individuals in areas where marginal vegetation was replaced.

Species P. vivipara and P. reticulata were considered as exotic species. These species are widely known for their ability to tolerate altered environments, occurring in places where a large number of species have limited distribution and dominate the environment in relation to native species. This fact, together with its reproductive adaptations with relative independence of the environmental variations, can favor its high number (Aranha and Caramaschi, 1999; Araújo et al., 2003; Teixeira et al., 2005). The presence of these species may pose a threat to the conservation of native ichthyofauna.

It is possible to consider that the low diversity and equability at point 2 are related to the abundance of $A$. burgerai. Araújo et al. (2007) related the occurrence of low values of these indices with the changes caused by anthropic activities and the resistance of the species. According to Tereza and Casatti (2010), the presence of opportunistic species is favored by the absence of riparian forest.

At point 6, the presence of only 3 species in the first sampling contributed to the lower found richness and probably is related to the present environmental changes, that is to say, habitat characteristics such as narrowing of the channel and human activity that strongly influenced the total number of individuals and the number of species (Melo et al., 2003).
On the other hand, the highest values of richness and diversity found at point 7 may be related to the fact that this part of the river had a larger area compared to other regions of the river itself and to other streams. Some authors associate the highest values of these indices to the width of the stretch, which may increase habitat heterogeneity and consequently greater shelter availability for different species (Castro et al., 2003; Araújo et al., 2007). These values are also favored by the presence of accidental species in the collections, as is the case of Astyanax sp. and Rineloricaria sp. The greater equability at point 3 may have been influenced by the absence of dominant species in this sampling, that is, the individuals distribute more homogeneously within the present species.

Although there was no statistically significant difference between the indices during the sampling, the results allowed to affirm that the presence of opportunistic species is probably associated with the lowest observed values, while the occurrence of accidental species was related to the verification of the highest values.

The relationship between abundance and biomass represented a slight numerical dominance of abundance and lower biomass for most points. At point 7, the result found in the $\mathrm{ABC}$ curve showed that there was a certain equilibrium between the two indexes, which shows that at this point a better environmental quality due to not having the advantage of one item in relation to the other.

This result was influenced by the high presence of smaller species, as is the case of the representatives of the genera Astyanax and Poecilia. The opportunistic character favors the dominance of these species with the 
increase of disturbances, where species of slow growth can not follow (Gonçalves and Braga, 2008), that is, in disturbed environments the assembly is composed of few small species that dominate in terms of abundance. At point 6 , the main reason for the positive result of the curves was the occurrence of species such as H. malabaricus and Hoplias sp. which represented little of the total abundance, but much in the body mass contribution, so when graphically represented the biomass curve overlaps with that of abundance. The low indexes verified, together with the negative values obtained by the $\mathrm{W}$ statistic in most of the sections, suggest a situation of environmental disturbance that can have as main stimulator the human occupation.

These results are complementary to those of the MDS statistics, whose absence of well defined groupings shows that there is no disparity in species composition between the points. Felipe and Súarez (2010) reported that homogenization occurs when there is a decline in environmental quality, since this condition increases the abundance of tolerant species. The result reflects an assemblage with high frequency of dominant species, being $A$. burgerai the species that contributes most to this effect.

One of the main problems of the Conservation Unit concerns land issues that have not yet been regularized, which explains the areas presenting vegetation in different stages of succession and the forms of land use and occupation (Casatti et al., 2009). In addition, the use of bioenergetic techniques to reduce the number of native vegetation losses, or permanent preservation areas or legal reserves, may lead to reduced fish biomass, loss of more sensitive species and higher chances of biotic homogenization.

Knowledge of ichthyofauna is the first step in the development of monitoring programs. This study suggests that REBIO - Una fish populations are influenced by the physical structure of the habitat, which is reflected in the composition of Ichthyofauna, structure in terms of abundance and biomass, and diversity. It also shows the need for more indepth studies in view of the strength that anthropic activities exert on the diversity of species studied.

\section{Acknowledgement}

To Biologist Maurício Nazarete Lopes for his collaboration in the preparation of the figures.

\section{References}

Aguiar PCB, Mareau AMSS and Fontes EO. (2012) Áreas naturais protegidas: um breve histórico do surgimento dos parques nacionais e das reservas extrativistas. Revista Geográfica de América Central 50: 95- 213.

Aquino PPU, Schneider M, Silva MJM, Fonseca PA, Arakkawa BH and Calvacanti DR. (2009) Ictiofauna dos Córregos do Parque Nacional de Brasília, Bacia do Alto Rio Paraná, Distrito Federal, Brasil Central. Biota Neotropica. 9: 217- 230.

Amorim AM, Jardim JG, Lo pes MMM, Fiaschi P, Borges R. AX, Perdiz RO and Thomas WW. (2009) Angiospermas em remanescentes de floresta montana no Sul da Bahia, Brasil. Biota N eotropical 9: 313-348.

Aranha JMR and Caramaschi EP. (1999) Estrutura populacional, aspectos da reprodução e alimentação dos Cyprinodontiformes (Osteichthyes) de um riacho do sudeste do Brasil. Revista Brasileira Zoologia 16:. 637- 651.

Araújo FG and Santos LN. (2001) Distribution of fish assemblages in lajes reservoir, Rio de Janeiro, Brazil. Revista Brasileira de Biologia. 61: 563- 57.

Araújo FG, Fichberg,I, Pinto BCT and Peixoto MG. (2003) A preliminary index of biotic integrity for monitoring the condition of the Rio Paraiba do Sul. Environ. Managem. 32: 516- 526. 
Araújo NB and Tejerina-Garro FL. (2007) Composição e diversidade da ictiofauna em riachos do Cerrado, bacia do ribeirão Ouvidor, alto rio Paraná, Goiás, Brasil. Revista Brasileira de Zoologia 24: 981- 990.

Casatti L. (2002) Alimentação dos Peixes in hum Riacho do Parque Estadual Morro do Diabo, Bacia do Alto Rio Paraná, Sudeste do Brasil. Biota Neotrop. 2: $1-14$.

Casatti L, Ferreira CP and Carvalho FR. (2009) Grassdominated stream sites exhibit low fish species diversity and dominance by guppies: an assessment of two tropical pasture river basins. Hydrobiol. 632: 273- 283.

Castro RJ, Foresti F and Carvalho ED. (2003) Composição e abundância da ictiofauna na zona litorânea de um tributário, na zona de sua desembocadura no reservatório de Jurumirim, Estado de São Paulo, Brasil. Acta Scientiarum Biol Sci. 25: 63-67.

Cetra M and Petrere JM. (2006) Fish-assemblage structure of the Corumbatai river basin, São Paulo State, Brazil: Characterization and anthropogenic disturbances. Brazilian J Biol. 66: 431- 439.

Cetra M, Ferreira FC and Carmassi AL. (2009) Caracterização das assembléias de peixes de riachos de cabeceira na bacia do rio Cachoeira (sudeste da Bahia). Biota Neotropica 9: 107- 114.

Cetra M, Sarm ento-Soares LM and Martins -Pinheiro RF. (2010) Peixes de riachos e novas Unidades de Conservação no sul da Bahia. Pan-American J Aquat Sci. 5: 11- 21.

Cotes M, Mielke MS, Cazorla IM and Moreal M. (2007) Avaliação do nível de dificuldade da trilha interpretativa do Ecoparque de UNA (BA). Revista Brasileira de Ciência do Esporte. 28: 191- 207.

Cote $M$ and Morel M. (2011) Analise da freqüência cardíaca e do discurso dos visitantes da trilha interpretativa da rppn ecoparque de una no trecho de passarelas suspensas no dossel. Lecturas Educación Físicay Deportes 162: 5.

Dajoz R. (1983) Ecologia Geral. São Paulo, (ed.) Vozes,. pp. 472.

Duncan JR and Lockwood JL. (2001) Extinction in a field of bullets: a search for causes in the decline of world's freshwater fishes. Biol Conserv. 102: 97-105.

Felipe TRA and Súarez YR. (2010) Characterization and influence of environmental factors on stream fish assemblages in two small urban sub-basins, Upper Paraná River. Biota Neotropical 10: 143-151.

Ferreira C and Casatti L. (2006) Influência da estrutura do hábitat sobre a ictiofauna de um riacho em uma micro-bacia de pastagem, São Paulo, Brasil. Revista Brasileira de Zool.23: 642-651.

Garutti V and Britski HA. (2000) Descrição de uma espécie nova de Astyanax (Teleostei: Characidae) da bacia do alto rio Paraná e considerações sobre as demais espécies do gênero na bacia. Comunicações do Museu de Ciências e Tecnologia, Série Zoologia, Porto Alegre 13: 65- 88.

Gomiero LM and Braga FMS. (2005) Uso do grau de preferência alimentar para a caracterização da alimentação de peixes na APA de São Pedro e Analândia. Acta Scientiarum Biol Sci. 27: 265- 270.

Gonçalves CS and Braga FMS. (2008) Diversidade e ocorrência de peixes na área de influência da UHE Mogi Guaçu e lagoas marginais, bacia do alto rio Paraná, São Paulo, Brasil. Biota Neotropica 8:103-114.

Guimarães ATB, Menezes MS and Peret AC. (2010) Ichthyofauna composition related to physiography in a coastal stream of Atlantic Forest, Brazil. Biota Neotropica 10: 58- 65.

Harding JS, Benfield EF, Bolstad PV, Helfman GS and Jones E.BD. (1998) Stream biodiversity: The ghost of land use past. PNAS 95:14843-14847.

Leal ME, Klein GF, Schulz UH and Lehmann P. (2010) First record and ecological aspects of Hoplerythrinus unitaeniatus (Agassiz, 1829) (Characiformes, Erythrinidae) as introduced species in Rio dos Sinos basin, RS, Brazil. Biota Neotropical 10: 33 -37.

Lowe-Mcconnell RH. (1999) Estudos ecológicos de comunidades de peixes tropicais. São Paulo, EDUSP, p. 584.

Malabarba LR. (1998) Monophyly of the Cheirodontinae, characters and majors clades (Ostariophysi: Characidae). In: Phylogeny and Classification of Neotropical Fishes, (eds.). Malabarba LR, Reis RE, Vari RP, Lucena ZMS and Lucena CAS, Edipucrs, Porto Alegre. pp. 193-233.

Malabarba L.R and Reis RE. (1987) Manual de técnicas para a preparação de col eções zoológicas. Peixes Sociedade Brasileira de Zoologia Campinas 36: 14.

Martins-Pinheiro AT, Sarmento-Soares LM, Aranda RF and Chamon CC. (2006 a) Ituglanis cahyensis, a new catfish from Bahia, Brazil (Siluriformes: Trichomycteridae). Neotropical Ichthyol. 4: 309- 318.

Martins-Pinheiro RF, Sarmento-Soares LM, Aranda AT and Chamon CC. (2006 b) Microglanis pataxo, a new catfish from southern Bahia coastal rivers, northeastern Brazil (Siluriformes: 
Pseudopimelodidae). Neotropical Ichthyol. 4: 157- 166.

Melo CE, Machado FA and Pinto-Silva V. (2003) Diversidade de peixes em um córrego de Cerrado no Brasil central. Brazilian J Ecol. 1- 2: 1-17.

Melo CE, Lima JD, Melo TLDE and Silva VP. (2005) Peixes do Rio das Mortes. Identificação e ecologia das espécies mais comuns. Cuiabá, Mato Grosso, Unemat editora p. 147.

Menezes NA. (1997) Padrões de distribuição da biodiversidade da Mata Atlântica do sul e sudeste brasileiro: peixes de Água doce. In: Workshop Padrões de Distribuição da Diversidade da Mata Atlântica do Sul e Sudeste do Brasil. 1997. Campinas.

Menezes NA, Weitzman SH, Oyakawa OT, Lima FCT, Castro RMC and Weitzman MJ. (2007) Peixes de água doce da Mata Atlântica. Lista preliminar das espécies e comentários sobre conservação de peixes de água doce neotropicais. São Paulo, Museu de Zoologia - Universidade de São Paulo. p. 407.

Oyakawa OT, Akama A, Mautari KC and Nolasco JC. (2006) Peixes de riachos da Mata Atlântica nas Unidades de Cons ervação do Vale do Rio Ribeira de Iguape no Estado de São Paulo. São Paulo, Editora Neotropica p. 201.

Polez VLP, Moraes G and Santos-Neto C. (2003) Different biochemical strategies of two Neotropical fish to cope with the impairment of nitrogen excretion during air exposure. Brazilian J Med Biol Res. 36: 279- 285.

Reis RE, Kullander SO and Ferraris JRCJ. (2003) Check list of the freshwater fishes of South and Central América. Porto Alegre - RS: EDIPUCRS. p. 742.

Rosa RS and Menezes NA. (1996) Relação preliminar das espécies de peixes (Pisces, Elasmobranchii, Actinopterygii) ameaçadas no Brasil. Revista Brasileira de Zool. 13: 647- 667.

Sarmento-Soares LM and Martins-Pinheiro RF. (2006) Mimagoniates sylvicola (Characidae: Glandulocaudinae): espécie ameaçada de extinção em riachos litorâneos do extremo sul da Bahia, Brasil. Boletim da Sociedade Brasileira de Ictiologia 83: 3-4.
Sarmento-Soares LM, Mazoni R and Martins-Pinheiro RF. (2007) A fauna de peixes na bacia do Rio Peruípe, extremo Sul da Bahia. Biota Neotropical 7 : 291- 308.

Sollberg I, Schiavetti A and Moraes MEB. (2014) Manejo agrícola no refúgio de vida de vida Sivestre de UNA: agroflorestas como uma prespectiva de conservação. Revista Árvore. 38: 241- 250.

Souza ERS. (2009) Hidroquímica fluvial e colimetria de uma bacia hidrográfica com diferentes graus de ocupação, localizada em um trecho de mata atlântica, no município de Una (Sul da Bahia). Dissertação de Mestrado (Programa de PósGraduação em Sistemas Aquáticos Tropicais). Universidade Estadual de Santa Cruz, Ilhéus, BA.

Teixeira T P, B enjamin CT P, Terra BF, Estiliano OE, Gracia $D$ and Araújo FG. (2005) Diversidade das assembléias de peixes nas quatro unidades geo gráficas do rio Paraíba do Sul. Iheringia. Zoologia Porto Alegre. 95: 347- 357.

Teresa F.B and Casatti L. (2010) Importância da vegetação ripária em região intensamente desmatada no sudeste do Brasil: um estudo com peixes de riacho. Pan-American J Aquatic Sci. 5: 444- 453.

Teodosio AS. (2012) Avaliação da integridade biótica em riachos da reserva biológica de Una, Bahia, Brasil. Dissertação de Mestrado (Programa de PósGraduação em Sistemas Aquáticos Tropicais). Universidade Estadual de Santa Cruz, Ilhéus, BA.

Thomaz WW, Carvalho AMV, Amorin AMA, Garrison J and Arbeláez AL. (1998) Plant endemism in two forests in Southern Bahia, Brazil. Biodiversity and Conservation. Chapman and Hall. vol. 7, p. 311- 322.

Vieira DB and Shibatta OA. (2007) Peixes como indicadores da qualidade ambiental do ribeirão Esperança, município de Londrina, Paraná, Brasil Daniel Bartolomei Vieira \& Oscar Akio Shibatta. Biota Neotropical 7: 57- 65.

Zanata AM and Camelier P. (2009) Astyanax vermilion and Astyanax burgerai: new characid fishes (Ostariophysi: Characiformes) from Northeastern Bahia, Brazil. Neotropical Ichthyol.7: 175 -184. 